ROCZNIKI HUMANISTYCZNE

Tom LXIX, zeszyt $1-2021$

DOI: https://doi.org/10.18290/rh21691-5

PAWE⿺ PANAS

\title{
PODRÓŻ DO BURMY GUSTAWA HERLINGA-GRUDZIŃSKIEGO - PERSPEKTYWY BADAWCZE. REKONESANS
}

W latach 1952-1953, na łamach wydawanych w Londynie przez Mieczysława Grydzewskiego Wiadomości ukazała się w siedmiu częściach Podróż do Burmy Gustawa Herlinga-Grudzińskiego. W późniejszym wydaniu książkowym pisarz opatrzył swój tekst podtytułem Dziennik, a także dodał do niego rodzaj posłowia, dyskretnie autointerpretacyjny esej, który zatytułował: $Z a$ miast posłowia: Stoń i... niepodległość. Obie decyzje autorskie w znaczący sposób wpłynęły - co oczywiste - na tryb lektury samego tekstu, wyznaczając dwa główne obszary zainteresowań piszących o tym dziele. Należy przy tym od razu zauważyć, że Podróż do Burmy nadal pozostaje na marginesie głównego nurtu zainteresowań badawczych twórczości Herlinga-Grudzińskiego, którzy nie poświęcają jej wciąż zbyt wiele należnej uwagi. Być może jednym z powodów tej sytuacji jest wpisana w ten tekst swoista doraźność, która jako taka podlega nieubłaganym procesom historycznej dezaktualizacji. $\mathrm{Z}$ pewnością natomiast uwagę większości badaczy przykuwał i nadal przykuwa przede wszystkim Dziennik pisany noca, na tle którego Podróż do Burmy może wydawać się jedynie rodzajem mniej lub bardziej udanej wprawki pisarskiej, ustępując pod wieloma względami właściwemu opus magnum pisarza (także w zakresie dojrzałości formy diarystycznej).

Pierwszy krąg zainteresowań to kwestie związane z gatunkową kwalifikacją tekstu, jego konwencjonalnością oraz wynikającymi stąd problemami natury interpretacyjnej. Jako pierwszy zwrócił na to uwagę Włodzimierz Bolecki,

Dr hab. PAWEŁ PANAS - adiunkt Instytutu Literaturoznawstwa na Wydziale Nauk Humanistycznych Katolickiego Uniwersytetu Lubelskiego Jana Pawła II; adres do korespondencji: Al. Racławickie 14, 20-950 Lublin; e-mail: pawel.panas@kul.pl; ORCID: https://orcid.org/0000-00027611-1992. 
pokazując wewnętrzną dynamikę w historii odbioru Podróży do Burmy w zależności od sposobu postrzegania jej prymarnej struktury literackiej:

W pierwodruku z 1953 roku Podróż do Burmy mogła sprawiać wrażenie, jak wspomniałem, przede wszystkim opóźnionej korespondencji prasowej, a w wydaniu książkowym z 1983 roku - reportażu z podróży. Z dzisiejszej perspektywy tamte gatunkowe opalizacje okazują się jedynie sytuacyjnymi składnikami kształtującej się wówczas nadrzędnej literackiej formy twórczości Herlinga - dziennika. (Bolecki 92)

Nie chodzi tu jednak wyłącznie o czysto akademickie rozważania z zakresu poetyki dzieła i związanej z nią historii odbioru. Prawdziwą stawką jest bowiem semantyka tekstu oraz kwestie natury ściśle interpretacyjnej. Ewoluujące rozumienie formy utworu pozwala dostrzec jego znaczeniową niejednoznaczność, a także uwypukla obecne w tekście istotne jakości uniwersalizujące.

Czytana jako dziennik Podróż do Burmy odsłania znacznie więcej warstw narracyjnych i tematów niż te, które są konsekwencją „zabicia słonia”. Pozwala dziś dostrzec, że polityczny wątek tej podróży wcale nie dominuje nad kompozycją relacji Herlinga. Ta podróż jest przede wszystkim wyprawą w nieznane - w inny obszar geograficzny i w inną kulturę. Herling nie jedzie do Burmy z „misją polityczną”, a w każdym razie nigdzie o takim celu nie wspomina (pisarz zresztą rzadko informuje o treści swoich odczytów). Jedzie ciekawy świata: krajobrazów, ludzi, architektury, obyczajów, a przede wszystkim chętny do rozmów i ciekawy losów swoich rozmówców. (92-93)

Kwestie gatunkowe stały się także przedmiotem osobnych rozważań Pawła Panasa, który poddał analizie wewnątrztekstowe napięcia w zakresie obecnych w utworze struktur i funkcjonujących w nim konwencji literackich. Jak pokazały przeprowadzone przy tej okazji analizy, Herling-Grudziński kształtuje swoją narrację według założeń zbliżonych do wzorca reportażu z podróży, jednocześnie świadomie przekracza go poprzez zastosowanie konwencji dokumentu osobistego.

W dziennikach Herlinga wyraźne napięcie formalne sytuuje się pomiędzy obszarami literatury faktu i dokumentu osobistego, esej - chociaż obecny - nie wydaje się szczególnie istotny z punktu widzenia strategii diarystycznej. Interpretacja jest raczej stałą skłonnością myślową pisarza - Grudziński zawsze dąży do zdarcia zasłony pozorów z obserwowanej przez siebie rzeczywistości - niż określoną konwencją pisarską. $(\text { Panas 152) })^{1}$

\footnotetext{
${ }^{1} \mathrm{Z}$ tezami tego artykułu częściowo polemizuje Jacek Hajduk, który stwierdził m.in.: „Sugestia, jakoby Podróż do Burmy i Dziennik pisany noca (bo Autor mówi: «dzienniki») konstytuowało
} 
Tym samym Podróż do Burmy jawi się jako istotny krok na drodze poszukiwania właściwej formy diarystycznej, zgodnej z pisarskim ideałem wielokrotnie i przy różnych okazjach werbalizowanym przez autora Dziennika pisanego noca.

Drugi krąg zainteresowań piszących o utworze Herlinga-Grudzińskiego również został niejako zasugerowany przez samego pisarza, który w zamykającym książkowe wydanie posłowiu przywołał jako bezpośredni kontekst dla swojego dziennika mniej znane „arcydzieło” (to opinia wyrażona przez Herlinga-Grudzińskiego) Georga Orwella Shooting an Elephant, tekst bazujący na doświadczeniu autora $\mathrm{z}$ jego pobytu w Birmie w latach 1922-1928. Pierwsza podążyła tym tropem Anna Nasalska. Badaczka widzi w Podróży do Burmy inspirowane Orwellem studium rozpadającego się imperium, którego upadek staje się początkiem narodzin nowej rzeczywistości totalitarnej. Wyczulenie Herlinga-Grudzińskiego na truciznę komunizmu oraz efekty jej praktycznej aplikacji sprawiają, że staje się on uważnym i jednocześnie wyraźnie zaniepokojonym obserwatorem zachodzących przemian:

Formalna otwartość dziennika, rejestrującego momenty jeszcze nie zinterpretowane i nie poddane selekcji, pozostaje w nieustannej kolizji z „wizją całościową”, będącą wynikiem wcześniejszych doświadczeń Herlinga. Pisarz jest świadkiem nastawania porządku sobie znanego i odczytuje w chaosie zjawisk elementy systemu. Rozpoznaje go przede wszystkim w języku używanym dla nazwania nowej rzeczywistości, w jego sloganach i magicznych formułach, w jego ideologicznej instrumentalizacji [...]. (Nasalska 192)

Istotnym elementem zaproponowanego przez Nasalską odczytania utworu Herlinga-Grudzińskiego jest jego odniesienie do sytuacji krajowej². Egzotyczna rzeczywistość obserwowana przez diarystyczny podmiot zostaje oswojona po-

napięcie pomiędzy literaturą faktu a literaturą dokumentu osobistego nie znajduje, moim zdaniem, poparcia - zresztą ani w jednym, ani w drugim punkcie. Żadne $\mathrm{z}$ tych dzieł nie jest reportażem, nie dąży do dokumentarności, żadne też nie ma charakteru intymnego, osobistego, ani nawet - ośmieliłbym się powiedzieć - prywatnego. [...] Szanując opinię Panasa, ja skłaniałbym się bardziej ku stwierdzeniu, że diarystyka Herlinga-Grudzińskiego jest nie tyle reportażem czy pamiętnikiem, ale po prostu esejem" (Hajduk 205). Polemika ta sprawia jednak wrażenie nie do końca celowej, ponieważ w ramach podstawowej narracji dziennikowej (a jest to rozpoznanie trudne do podważenia z punktu widzenia genologicznego; trudno zgodzić się z Hajdukiem, który Podróż do Burmy nazywa esejem) można w przypadku obu wspomnianych dzieł mówić raczej o współistnieniu innych mniej lub bardziej istotnych tendencji narracyjnych, w tym - rzecz jasna - także typowej dla diarystyki tendencji eseistycznej. Tendencja ta nie wyklucza jednak obecności istotnych elementów reportażowych oraz intymistycznych.

${ }^{2}$ Pamiętajmy, że pierwodruk omawianego artykułu ukazał się na łamach Kultury Niezależnej w 1989 r. 
przez analogie do dobrze znanej pisarzowi sytuacji panującej w rodzinnym kraju, analogii - dodajmy - niezwykle gorzkiej. Procesy polityczno-społeczne zachodzące w Birmie w pewien sposób przypominają te, które kształtowały powojenną rzeczywistość w Polsce. Stąd już tylko krok od stwierdzenia, że właściwym, chociaż nie wywoływanym wprost, odbiorcą jest czytelnik krajowy, który ze względu na wspólne doświadczenia może w pełni zrozumieć sposób myślenia autora. Analogia ta - dodajmy - działa w obie strony: pobyt w Birmie przywodzi na myśli ojczyznę pisarza i zmusza do refleksji nad jej aktualnym stanem i dalszymi losami. W ten sposób kończy swój wywód Nasalska:

Los Polski z tego punktu globu ziemskiego wygląda równie ponuro i beznadziejnie. W powściągliwej, unikającej intymności relacji Herlinga można usłyszeć jakby załamanie głosu: „Trzeba było Burmy i tego - niedosłyszalnego w Londynie - dudnienia kropel deszczu o drewniane dachówki abym poczuł nagle pierwszy od tylu lat przypływ nostalgii”. Spowodowany porą deszczową, ale może i tym nie planowanym powrotem do kraju. W egzotycznej przestrzeni rozwija się przecież ten sam scenariusz historycznego dramatu, przy tej samej obojętności widowni. (194)

Tym samym tropem wyznaczonym przez Herlinga-Grudzińskiego podąża również, wspomniany już wcześniej, Jacek Hajduk. W swoim erudycyjnym szkicu skupia się on na kolonialnych i (anty)imperialistycznych wątkach obecnych w Podróży do Burmy ${ }^{3}$. Dziennik w tym ujęciu stanowi interesujące świadectwo działania różnego rodzaju mechanizmów wewnętrznych i zewnętrznych sterujących przemianami cywilizacyjnymi, społecznymi i politycznymi w kraju, który jest w trakcie odzyskiwania swojej tożsamości i prawdziwej autonomii. Dlatego też utwór Herlinga-Grudzińskiego jest wciąż aktualną i ważną lekturą jako doskonałe źródło obserwacji i refleksji nad zawiłą i często niejednoznaczną naturą tych procesów. Jest także - jak pokazuje Hajduk - głęboko humanistycznym głosem w sprawie ocalenia prymatu jednostki ludzkiej jako właściwego punktu odniesienia dla wszelkich działań:

Kiedy z oczu traci się istotę rzeczy - człowieczeństwo - nawet to, co najczystsze i najszlachetniejsze, może przybrać formę niebywałego okrucieństwa. Oto więc historia birmańskich przemian, rejestrowana bez taryfy ulgowej przez Orwella i HerlingaGrudzińskiego na dwóch jej różnych etapach, tj. u szczytu kolonializmu i w samym oku postkolonialnego cyklonu, dopisała się niejako sama. Niepodzielnie rządzący w Birmie buddyzm znowu dostarczył paliwa politycznej machinie - tym razem,

\footnotetext{
${ }^{3} \mathrm{~W}$ omawianym już wcześniej artykule konstatował Bolecki: „Gdyby Herling napisał Podróż do Burmy po angielsku, jego dziennik zaliczony byłby dziś do klasyki tzw. literatury postkolonialnej” (Bolecki 94).
} 
niestety, jako potwierdzenie słynnych słów lorda Actona, że „władza demoralizuje, a władza absolutna demoralizuje absolutnie". (Hajduk 219)

Przedstawione tu pokrótce prace właściwie wyczerpują stan badań dotyczący Podróży do Burmy Gustawa Herlinga-Grudzińskiego. Jak widzimy, osobnych tekstów poświęconych wczesnemu dziennikowi pisarza jest niewiele, a podejmowana przez kolejnych interpretatorów problematyka w naturalny sposób ulega dosyć szybkiemu wyczerpaniu. Pewne szanse na dalszy rozwój rokuje jedynie lektura nakierowana bezpośrednio na obecną w utworze problematykę postkolonialną. To właśnie w tym zakresie można zaplanować dalsze dociekania prowadzące $\mathrm{w}$ jednym $\mathrm{z}$ dwóch kierunków. Po pierwsze, warto zastanowić się nad skomplikowanym, osobistym dziedzictwem historycznym i kulturowym pisarza oraz jego (dziedzictwa) modelującym wpływem na postrzeganie przez autora egzotycznej rzeczywistości. Badania tego typu mają już całkiem bogatą tradycję także w polskim literaturoznawstwie, a omawiany tu przypadek na pierwszy rzut oka wydaje się niezwykle interesujący. Po drugie, osobnym zagadnieniem zasługującym na głębsze rozpoznanie pozostaje także kwestia umiejscowienia utworu na mapie literatury postkolonialnej w ogóle. Można zadać bowiem istotne pytanie, czy i w jaki sposób Herling-Grudziński wpisuje się tu w określoną tradycję rozumienia i opisywania problematyki imperialnej oraz budzenia się świadomości wybijającej się na niepodległość dawnej kolonii. W obu przypadkach możemy spodziewać się wyjątkowo interesujących ustaleń, które potencjalnie mogą mieć także duże znaczenie dla lepszego zrozumienia niektórych, słabo dotąd obecnych wątków w historii dwudziestowiecznej literatury polskiej i jej miejsca na mapie literatury światowej.

Zauważmy jednak, że zaprojektowane w ten sposób badania wyprowadzają nas niejako poza bezpośredni obręb twórczości pisarza i nie pozwalają dostrzec szczególnej roli i miejsca Podróży do Burmy w jego pisarstwie. Jakkolwiek poznawczo cenne, nie dają nam bowiem właściwych narzędzi, aby w pełni docenić i zrozumieć ten utwór na tle późniejszych dokonań autora Innego świata. Jest to o tyle ważne, że - jak można się łatwo przekonać po lekturze prac poświęconych interesującemu nas tekstowi - wczesny dziennik pisarza traktowany był dotychczas niejako w izolacji od jego macierzystego kontekstu. To prawda, doceniano sam utwór, chociażby Hajduk pisał o nim jako o eseju najwyższej próby (Hajduk 204). Kiedy już jednak myślano o nim w kategoriach jednego z elementów większej całości, przeważnie przywoływano wyłącznie - co oczywiście można zrozumieć - Dziennik pisany noca, 
a więc w pełni dojrzałe, rozpisane na wiele wątków, lat i tomów arcydzieło polskiej diarystyki. Podobne zestawienia z konieczności musiały oczywiście wypadać na niekorzyść Podróży do Burmy, sytuując ją w pozycji swoistej wprawki, być może niezamierzonej praktyki pisarskiej na drodze do wypracowania własnej formuły dziennikowej, jednym słowem - tekstu pozostającego w cieniu swoistego opus magnum pisarza. Wyjątek stanowią tu jedynie marginalne uwagi wieńczące świetny szkic Boleckiego, w których badacz zauważył, że w twórczości Herlinga-Grudzińskiego pojawiają się pewne motywy lub chociażby ich odległe reminiscencje, które po raz pierwszy zaistniały właśnie w Podróży do Burmy. Dotyczy to nie tylko Dziennika pisanego noca, ale także Innego świata, a przede wszystkim opowiadań. Bolecki wymienia tu Księcia Niezłomnego, Most, Wieże, Goracy oddech pustyni, Szczyt lata. Opowieść rzymska i Prochy. Swój krótki wywód kończy zaś nieco przenośnym, choć przecież adekwatnym w tym kontekście stwierdzeniem: „Podróż do Burmy trwała trzy tygodnie, ale to, co pisarz z niej przywiózł, żyje w jego twórczości już blisko pół wieku" (Bolecki 97).

Metaforycznego trwania, o którym mówi Bolecki, nie trzeba ograniczać jedynie do pojawienia się w innych tekstach kilku, niekiedy dosyć mocno już przeobrażonych motywów czy obrazów. Uważny interpretator może poszerzyć tę listę także o zbliżone rozwiązania fabularne, powtarzające się chwyty narracyjne, czy wreszcie rozpoznawalne właściwości stylu pisarza, na przykład szczególną predylekcję do konstruowania silnie zindywidualizowanych fragmentów opisowych na podstawie środków świadomie odwołujących się do zmysłowych wrażeń podmiotu. Zestawmy ze sobą chociażby dwa poniższe charakterystyczne fragmenty, pierwszy pochodzący z Podróży do Burmy, drugi - z opowiadania Zjawy Saraceńskie:

Złoty Budda Mahamuni siedzi w głębi głównej nawy. Na wysokości jego pępka widać rusztowanie, a na nim trzech uwijających się mężczyzn, którzy nieustannymi ruchami rąk jak gdyby poprawiają coś w posągu. Oglądany od progu pagody, robi wrażenie olbrzymiej złotej ryby w akwarium napełnionym zieloną wodą i fioletowo-niebieskimi wodorostami; nieco bliżej ta płynność okazuje się po prostu powietrzem drżącym od upału i niezliczonych płomieni świec. Zachęceni przez przewodnika, wdrapujemy się na rusztowanie, ale jedna $\mathrm{z}$ belek przywiera tak ściśle do posągu, że aby przejść do przodu i stanąć oko w oko z Buddą, trzeba na zakręcie oprzeć się rękami o jego ramię. Czuję obiema dłońmi gorącą lepkość jakiejś mazi i prześlizgnąwszy się szybko na przedni pomost rusztowania, odrywam z instynktownym uczuciem wstrętu ręce od posągu: są ubabrane złotem. I dopiero teraz dostrzegam jednocześnie co robią trzej mężczyźni na rusztowaniu: oblepiają Buddę cienkimi płatkami kleistej pozłoty, odwijając je ostrożnie z listków papieru. (Herling-Grudziński, Podróż 36) 
W kolejce kościelnej nie odrywałem oczu od Padre Pio, idąc ku niemu. Z początku uderzała bezduszność jego ruchów, wyglądał jak urzędnik stemplujący automatycznie podsuwane mu przez interesantów papierki. Było to złudzenie zbyt wielkiego dystansu. W miarę zbliżania się Padre Pio ulegał dziwnym przemianom; stojąc przed ołtarzem, w miejscu gdzie zazwyczaj ksiądz za niską przegrodą przesuwa się w trakcie udzielania komunii, nie przestawał co prawda być wiejskim oschłym i mało wyrozumiałym plebanem, ale w jego ruchach błogosławienia lub ozdrowieńczego dotykania, a niekiedy nawet głaskania głowy zauważało się odcień czułości. Był przejęty swoim cudotwórczym darem? Starał się towarzyszyć nieszczęsnym? Takie sprawiał wrażenie. Odetchnąłem z ulgą. Tak samo Elisabetta, spostrzegłem to natychmiast. Jedyna w kolejce szła naprzód na wyprostowanych nogach, popychając wózek córki. Reszta posuwała się na klęczkach, niektórzy nawet czołgali się, przekonani zapewne, że w tej pozycji spodobają się bardziej Bogu i jego wysłannikowi. Z bliska widziałem dobrze mokre rękawiczki Padre Pio i wstrzymywałem oddech, owiany zapachem jego ciała. (Herling-Grudziński, Opowiadania 364)

Podobne przykłady można oczywiście mnożyć. Interesujące mnie tutaj podobieństwa czy interferencje za każdym razem mają nieco inny wymiar, służą też różnym celom, jednak dokładne analizy tekstowe mogłyby - jak sądzę ujawnić w tym względzie pewne prawidłowości. Dlatego też potrzebne jest ponowne przemyślenie Podróży do Burmy właśnie jako tekstu stricte literackiego. Nie chodzi tu jedynie o kwestie ściśle gatunkowe. Konstatacje genologiczne (co widzieliśmy) dostarczają nam w tym przypadku poręcznych formuł służących przedstawieniu poetyki utworu, ale jednocześnie niosą ze sobą niebezpieczeństwo ulegnięcia pokusie sprowadzenia go do przykładu mniej lub bardziej udanej realizacji określonej konwencji. Ciekawsze poznawczo a jednocześnie wciąż czekające na opisanie może się natomiast okazać wszystko to, co nie mieści się w prostych wzorcach gatunkowych i co wykracza poza prymarny, diarystyczny punkt odniesienia. $Z$ tego punktu widzenia warto raz jeszcze przyjrzeć się bliżej kompozycji tekstu, konstrukcji podmiotu, strukturze fabularnej, rytmice narracji czy chociażby kwestiom związanym z budową partii opisowych. Co więcej, można, a nawet trzeba spojrzeć na te zagadnienia nie tylko w sposób immanentny, ale pokusić się także o porównanie z późniejszymi, bardziej znanymi tekstami pisarza. Dzięki temu Podróż do Burmy może okazać się ważnym punktem odniesienia na mapie twórczości HerlingaGrudzińskiego niezależnie od jej chronologicznego układu. Konsekwencją tego może być zatem także choćby częściowa zmiana wewnętrznej hierarchii tego pisarstwa i jednoczesne dowartościowanie wczesnego dziennika autora Innego świata. 


\title{
BIBLIOGRAFIA
}

Bolecki, Włodzimierz. Ciemna Miłość. Szkice o twórczości Gustawa Herlinga-Grudzińskiego. Wydawnictwo Literackie, 2005.

Hajduk, Jacek. „Birma, Orwell i Herling-Grudziński”. Świadectwo - Mit-Tajemnica. O Gustawie Herlingu-Grudzińskim, red. Zdzisław Kudelski, Narodowe Centrum Kultury, 2019, ss. 203-220.

Herling-Grudziński, Gustaw. Podróż do Burmy. Puls Publication, 1983.

Herling-Grudziński, Gustaw. Opowiadania wszystkie, t. 2. Wydawnictwo Literackie, 2017.

Nasalska, Anna, „Śladami Orwella. O Podróży do Burmy Gustawa Herlinga-Grudzińskiego”. Etos i artyzm. Rzecz o Herlingu-Grudzińskim, red. Seweryna Wysłouch, Ryszard Kazimierz Przybylski, Wydawnictwo a5, 1991, ss. 186-194.

Panas, Paweł. „Między literaturą faktu a literaturą dokumentu osobistego. Uwagi o strukturze Podróży do Burmy Gustawa Herlinga-Grudzińskiego". Roczniki Humanistyczne, t. 57, z. 1, 2009, ss. 145-154.

\section{PODRÓŻ DO BURMY GUSTAWA HERLINGA-GRUDZIŃSKIEGO - PERSPEKTYWY BADAWCZE. REKONESANS}

\section{Streszczenie}

Artykuł podejmuje problematykę dotychczasowych badań nad mniej znanym, wczesnym dziennikiem Gustawa Herlinga-Grudzińskiego z okresu jego podróży do Birmy (Podróż do Burmy). Autor wyróżnia dwa zasadnicze wątki interpretacyjne obecne w najważniejszych tekstach poświęconych temu utworowi. Są to: zagadnienia genologiczne oraz kwestie historyczno-polityczno-społeczne. Pokazując zalety i osiągnięcia tych prac, badacz wskazuje także na te elementy, które nadal nie doczekały się dokładnej analizy. I tak podkreślona zostaje potrzeba pogłębionej lektury dzieła Herlinga-Grudzińskiego z uwzględnieniem perspektywy postkolonialnej, a także bliższe przyjrzenie się temu tekstowi w kontekście całej twórczości autora Podróży do Burmy i specyfiki jego sztuki pisarskiej. W artykule szczegółowo omówione zostały główne problemy, ale także potencjalne korzyści każdego z tych podejść.

Słowa kluczowe: Podróż do Burmy; Gustaw Herling-Grudziński; postkolonializm; close reading

\author{
RESEARCH PERSPECTIVES ON A JOURNEY TO BURMA \\ BY GUSTAW HERLING-GRUDZIŃSKI: AN EXPLORATION
}

\section{S u m m a ry}

This article concerns the existing research on the lesser-known, early diary of Gustaw Herling-Grudziński about his journey to Burma titled A Journey to Burma. In this article, the author distinguishes two main interpretative themes appearing in the most important texts dealing with this work: genealogical issues, and those related to history, politics and social life. By showing the advantages and effects of these texts, the author points to those elements that still have not been thoroughly analysed. Thus, the need for an in-depth reading of this work with the post-colonial perspective taken into account is emphasised, as is a closer look at this text in the context of the whole output of the author of A Journey to Burma and his unique writing style. This article discusses in detail the main problems and potential benefits of each approach.

Keywords: A Journey to Burma; Gustaw Herling-Grudziński; postcolonialism; close reading 